\title{
Growing Feijoa Fruit in Florida
}

\author{
Kevin M. Folta, Dustin Huff, and Ali Sarkhosh²
}

The fruits from Feijoa sellowiana Berg (feijoa) are also known as pineapple guava or guavasteen (Figure 1). Feijoa belongs to the Myrtaceae family, which also includes the common guava Psidium guajava, though it is distinctly different. The feijoa is native to southern Brazil, northern Argentina, Paraguay, and Uruguay, and is grown throughout the world in tropical and subtropical climates, with an occasional incursion into protected temperate environments. Egg-sized fruits are harvested from a slow-growing shrub that may be trained as a tree. The leaves have a glossy, dark-green topside and a white, felt-like underside. Large caliper stems develop a gray-colored bark. Feijoa is often found in central and north Florida landscapes as a durable and cold-hardy plant for hedges and foundation plantings, and as a dooryard fruit. Its value as a potentially heavy producer of flavorful fruits (and flavorful flowers) is frequently overlooked due to issues in pollination and limited genetic improvement.

\section{Production Areas}

Most commercial feijoa production is in New Zealand, and it is also grown in Uruguay, Japan, Italy, and western Georgia and Azerbaijan near the Black Sea. Commercial production in the United States is confined to several small operations in California. Yields have been reported as high as 15-20 tons per hectare at maturity. Because of the low pressure from diseases and pests, feijoa is well suited for organic cultivation.

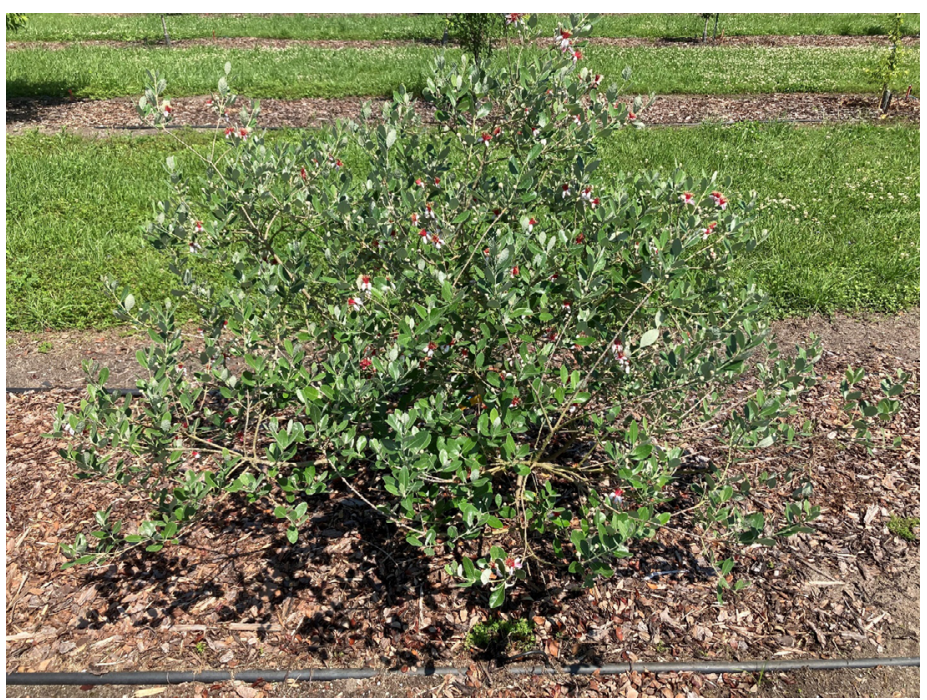

Figure 1. Two-year-old feijoa grown in Florida. Credits: Dustin Huff, UF/IFAS

\section{Growing Conditions}

Feijoa thrives in Mediterranean climates. It can be grown in zones $8-11$, but tree injury is likely below $20^{\circ} \mathrm{F}$, and fruit injury below $28^{\circ} \mathrm{F}$. Chilling appears to be required for flower bud initiation, although the amount required is poorly studied and cultivar dependent. Estimates are documented at between 50-200 hours, yet little fruiting is observed south of the I-4 corridor (Orlando-Tampa latitude), which averages 200 chilling hours per year. The plants are well suited for coastal regions because they tolerate salt spray. High heat can damage the fruits (above $100^{\circ} \mathrm{F} / 38^{\circ} \mathrm{C}$ ), especially when accompanied by low humidity.

1. This publication is HS1424, one of a series of the Horticultural Sciences Department, UF/IFAS Extension. Original publication date December 2021. Visit the EDIS website at https://edis.ifas.ufl.edu for the currently supported version of this publication.

2. Kevin Folta, professor; Dustin Huff, biological scientist; and Ali Sarkhosh, assistant professor and Extension specialist; Horticultural Sciences Department, UF/IFAS Extension, Gainesville, FL 32611.

The Institute of Food and Agricultural Sciences (IFAS) is an Equal Opportunity Institution authorized to provide research, educational information and other services

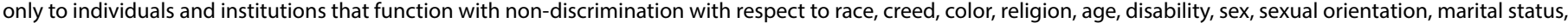

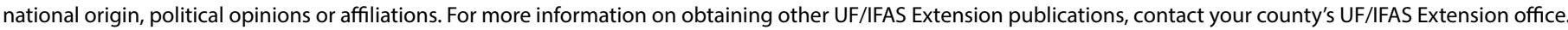
U.S. Department of Agriculture, UF/IFAS Extension Service, University of Florida, IFAS, Florida A \& M University Cooperative Extension Program, and Boards of County Commissioners Cooperating. Andra Johnson, dean for UF/IFAS Extension. 
Feijoa grows best in well-drained soils with a $\mathrm{pH}$ of 5.5-7.0. It can grow well without supplemental irrigation, yet prolonged dry periods can lead to fruit and leaf drops. Fruit matures between 20 and 26 weeks after flowering and mostly overlaps with the rainy season in Florida. The tree grows well in full sun and part shade.

Wind may cause fruit bruising, and weaker branches may be damaged. A site protected from stronger winds is suggested.

\section{Cultural Practices}

\section{Propagation}

Clonal propagation is a challenge in feijoa, with most reports indicating limited success. Three-node cuttings with the top two leaves attached taken in November-December have shown some success when 3000 ppm IBA solution is applied and bottom heat is provided. Cuttings can also be taken in July-August from the middle to lower sections of branches that are approximately $1 / 5$ " in diameter. Softwood cuttings have a lower success rate, though a misting system may improve the odds. Air layering and ground layering of low-hanging branches are additional options.

Grafting is difficult because the wood is hard and splits easily. Successful grafts have been obtained using cleft and whip-and-tongue grafts. It is advisable to graft multiple cultivars onto a common rootstock. 'Precocious' is a good cultivar to include because its long flowering habit allows it to serve as a pollen parent throughout the flowering season of other cultivars (Figure 2). The addition of 'Precocious' to a multivariety grafted tree does not appear to influence flowering of other cultivars.

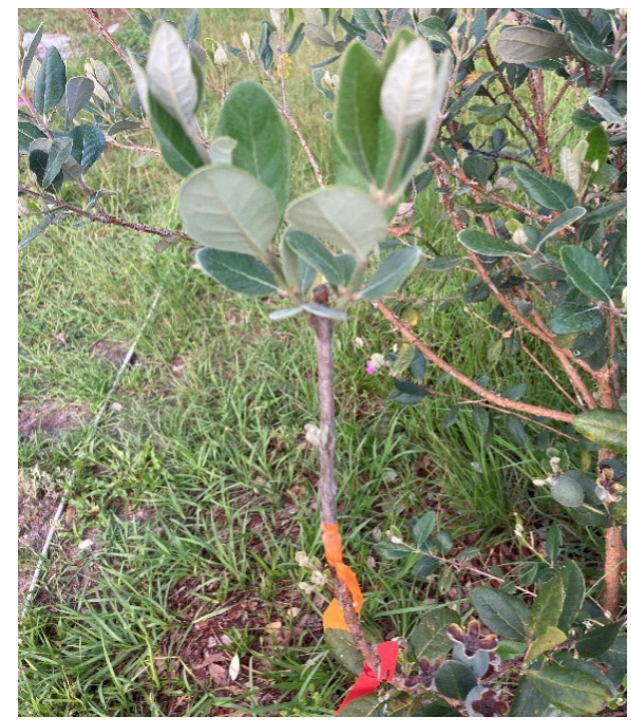

Figure 2. Feijoa varieties may be propagated by grafting to established landscape feijoa plants. Here 'Rannaya' is grafted using a cleft graft. Credits: Kevin Folta, UF/IFAS
Feijoas are relatively easy to start from seed, because seed dormancy is not a concern, and they can be planted immediately after removing from the fruit. However, the resulting plants will likely not be true-to-type, meaning that they will be genetically different from the mother plant. These seedlings may also be used as rootstocks for desirable scion cultivars, because improved rootstocks have not been developed.

\section{Cultivars and Genetic Variation}

Most feijoa cultivars arise from a narrow genetic base, with many named cultivars arising from Uruguay, California, and New Zealand (Table 1). Modern genetic improvement efforts by private breeding programs in New Zealand have developed new cultivars with substantially larger fruits approaching $300 \mathrm{~g}$. Several genetic improvement programs seek to combine the traits of self-fertility, high yields, consistent shape/size in fruit, good flavor, high sugar content, acceptable shipping, and shelf life.

\section{Flowering}

In Florida, feijoa begins flowering in April and may continue for 60 days, depending on the cultivar (Figure 3). Flowers progress from early opening to senescence in eight days.

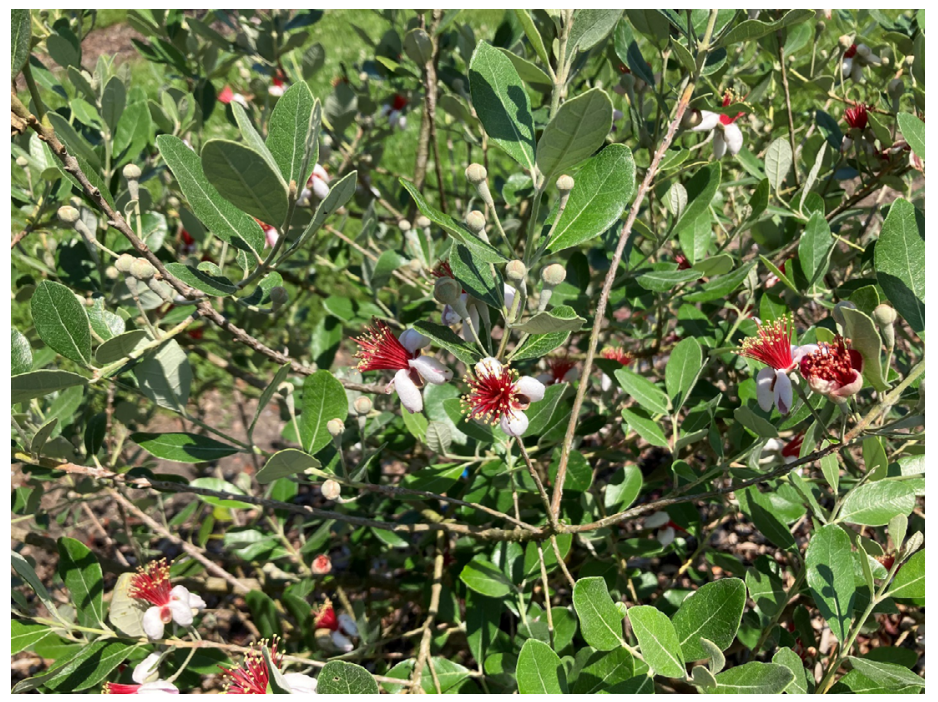

Figure 3. Flowering feijoa mid-April in Florida. Credits: Dustin Huff, UF/IFAS

Flower buds originate from leaf axils in the current year's growth and develop in synchrony with a vegetative flush. The red-white flowers are hermaphroditic, bearing many stamens and one elongated carpel (Figure 4).

Some self-fertile varieties have been described and are reported to present higher yields, especially when crosspollinated with other varieties. 


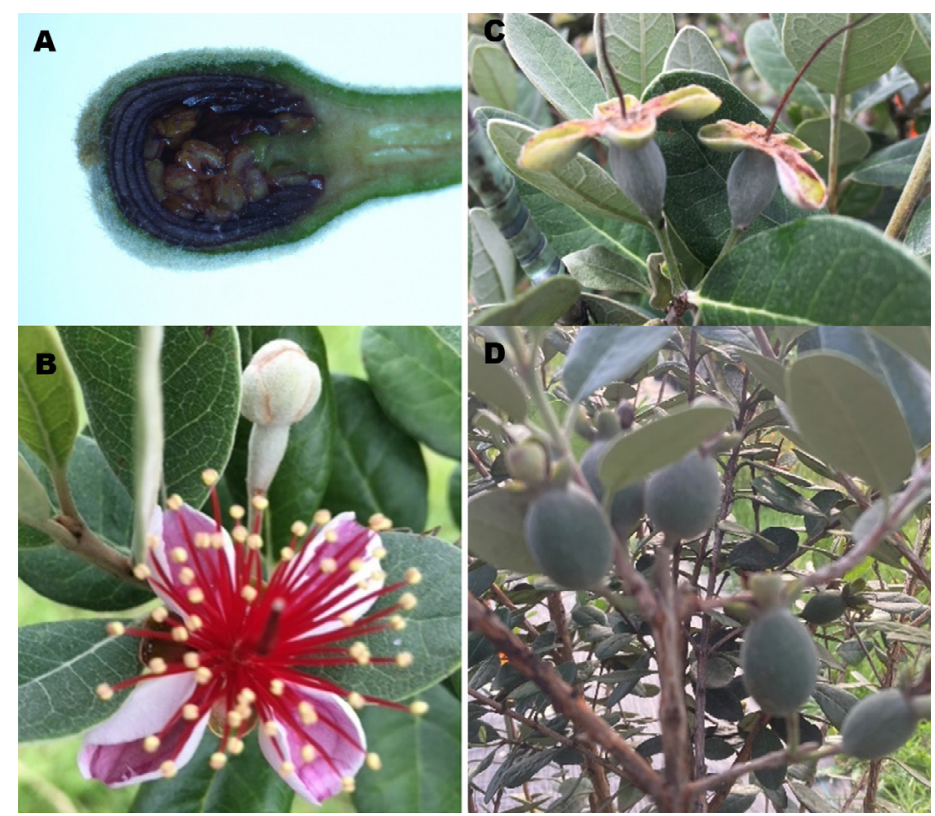

Figure 4. Feijoa bud, flowers, and fruit. (A) Developing feijoa flower bud (mid-March; microscopic photo). (B) Feijoa flowers are showy, fragrant, and taste like strawberry and pineapple (mid-April). (C) Feijoa fruits begin developing shortly after flower senescence (mid-May). (D) Developing feijoa fruits growing in clusters (mid-June).

Credits: Kevin Folta and Dustin Huff, UF/IFAS

Self-incompatible trees preferentially outcross to produce fruit and depend on bees and birds for pollination. Pollen grains are small and likely carried on wind. Bees have been shown to be less effective pollinators due to their small size and their tendency to harvest pollen that may be unavailable for larger pollinators to move. Honeybees also have been shown to be more likely to visit flowers within the same tree, making them less effective pollinators.

\section{Spacing, Training, Pruning}

The evergreen feijoa trees are generally slow-growing and may be trained as a shrub, hedge, or tree. Between-plant spacing is typically 7-14 ft (2-4 m), depending on whether a hedged design or individual trees are desired (Figure 5). Rows are commonly spaced at $12-15 \mathrm{ft}(4-5 \mathrm{~m})$. For in-hedge cultivation, growers allow only the 5-6 strongest basal trunks to grow. When training as a tree form, a single trunk with 4-6 branches is maintained, and at maturity trees can reach a height of 10-15 ft (3-5 m). Minimal pruning is necessary, other than to develop and maintain desired structure (hedge vs tree). Shoots can be shortened to control branch spread or lighten the canopy to allow more effective dispersal of spray treatments if necessary. Fruit thinning is not typically done for feijoa. The shallow rooting of feijoa precludes cultivation around the plants, so maintaining grass strips between rows and weed-free zones in rows by mulch or herbicide applications is common.

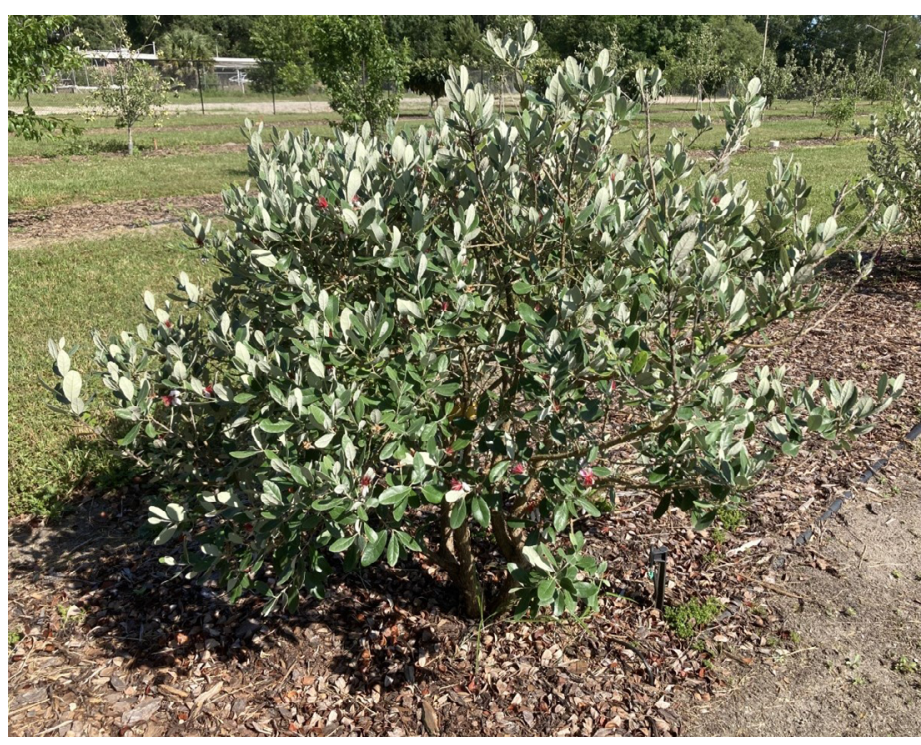

Figure 5. Young feijoa with mulch in-row and grass strips between rows.

Credits: Dustin Huff, UF/IFAS

\section{Fertilization}

Little is known about the nutrient requirements of feijoa production in Florida.

Conventional fertilizers, such as 10-10-10 or 8-3-9, may provide adequate nitrogen, phosphorus, and potassium. It is also essential to provide secondary nutrients and micronutrients to maximize plant health and fruit quality. Secondary nutrients include magnesium and sulfur, and micronutrients include boron, nickel, manganese, copper, zinc, and iron. Nutrients may be applied either as fertigation (liquid fertilizer applied through irrigation lines), as a granular fertilizer, or via foliar feeding. If granular fertilizer is used, small amounts $(0.5 \mathrm{lb} /$ plant to $1 \mathrm{lb} /$ plant for young plants and no more than $2 \mathrm{lb}$ for mature plants) should be made from late winter through fall on 4-to-6-week intervals.

\section{Fruit Development and Harvest}

Evidence of successful pollination in feijoa is observed within two weeks of pollination. As in other myrtles, ovary and fruit development occur below the base of the flower. The fruits are ovoid, with typical weights of 1-2 oz. Each contains 3-4 locules with numerous seeds.

The first harvest of fruit happens 2-4 years after planting, and plants reach maturity and full fruiting at 8-10 years. In a backyard setting, it is recommended to wait for the first fruits to fall off to determine when to harvest. Commercially, harvest begins when fruit is easily detached from the branch with minimal force, or by shaking the tree and collecting on tarps. Some softening and a color change to a 
lighter green also indicate ripeness. Harvest begins as early as September and lasts through November, depending on variety. The estimated production life of feijoa is $30-40$ years, but specific data is not available for Florida. Harvested mature fruit can be stored between $0^{\circ} \mathrm{C}-4^{\circ} \mathrm{C}$ for $4-7$ weeks, or approximately one week at room temperature.

\section{Pests and Diseases}

In the southeastern United States, feijoa has no reported consistent pests or pathogen threats. Fruit flies and black scale have been reported in California. In New Zealand and South America insect pests like scale, thrips, and some species of fruit flies have been reported. There also have been reports of fruit rot from anthracnose (Colletotrichum gleosporoides Penz.). Fungal pathogen information on feijoa is not available in Florida. Because of the rainy season overlapping with the flowering and fruit development period, fungicide applications will likely be needed occasionally.

\section{Fruit Quality and Uses}

Feijoa has a distinct, strong fruity flavor and aroma reminiscent of pineapple mixed with the presence of other fruity, sweet-sour notes. The major volatile compounds are methyl and ethyl benzoate, octan-3-one, and linalool, which represent approximately $90 \%$ of the aromatics. The fruits are unusually high in iodine $(2.0-4.0 \mathrm{mg} / \mathrm{kg})$.

Fruits have been described as fragile with bruising common, and some varieties (e.g., 'Mammoth') have been shown to be hollow and pulpless from self-pollination. 'Nazemetz' internal fruit flesh is reported to be nonbrowning upon exposure to air, which may be an attractive trait for consumer acceptance and fresh-fruit consumption.

Some uses of feijoa fruit in Brazil are fresh, as a dessert fruit, and canned or jellied. Fruit are eaten fresh by cutting in half and scooping out the inside, similar to a kiwifruit. It is also used in making medicinal products, juice and alcoholic drinks, and candy. The pulp can be a substitute in a recipe calling for banana or apple.

\section{Invasiveness}

Feijoa is not invasive in Florida, according to the federal and state Noxious Weed Lists. Also, it is not a problem species according to the UF/IFAS Assessment of the Status of Non-Native Plants in Florida's Natural Areas (UF/IFAS 2018), because it has not been found in undisturbed areas.

https://assessment.ifas.ufl.edu/assessments/

feijoa-sellowiana/

\section{Conclusion}

Feijoa has seen sporadic enthusiastic adoption as a relatively disease-free, low-maintenance, tasty fruit. However, unpredictable problems with pollination, lack of uniformity in fruit size, and other horticultural problems make feijoa more appropriate for small-size cultivation targeting specialty markets. Efforts in genetic improvement may standardize fruit quality and tree productivity.

\section{References}

California Rare Fruit Growers. n.d. "Feijoa." Accessed 6/25/21. https://crfg.org/wiki/fruit/feijoa/

Dirr, M. A., and C. W. Heuser Jr. 2012. The Reference Manual of Woody Plant Propagation: From Seed to Tissue Culture. 2nd ed. Portland: Timber.

Jackson, D., N. E. Looney, and M. Morley-Bunker (Eds.). 2011. Temperate and Subtropical Fruit Production. CABI. https://doi.org/10.1079/9781845935016.0000

Morton, J. F. 1987. Fruits of Warm Climates. Miami: JF Morton.

Ramírez, F., and J. Kallarackal. 2017. "Feijoa [Acca sellowiana (O. Berg) Burret] Pollination: A Review." Scientia Horticulturae 226:333-341. https://doi.org/10.1016/j. scienta.2017.08.054

Sharpe, R. H., W. Sherman, and E. P. Miller. 1994. "Feijoa History and Improvement." Proceedings of the Florida State Horticultural Society 106:134-138.

Stewart, A. M., and J. L. Craig. 1989. "Factors Affecting Pollinator Effectiveness in Feijoa sellowiana." New Zealand Journal of Crop and Horticultural Science 17 (2): 145-154. https://doi.org/10.1080/01140671.1989.10428023

Waimea Nurseries. n.d. "Feijoa Varieties for Fruit Growers." Accessed 7/3/2021. https://commercial.waimeanurseries. co.nz/assets/Uploads/Comm-Feijoas/WAIMEA-FeijoaBrochure.pdf 
Table 1. Some of the feijoa cultivars grown in the USA.

\begin{tabular}{|c|c|c|c|c|}
\hline Cultivar & Origin & Fruit Size & Self Fertile* & Other Notes \\
\hline Apollo & New Zealand & Medium to large & + & $\begin{array}{l}\text { Large, vigorous tree, early sweet fruit without } \\
\text { characteristic grit and astringency. Excellent flavor. }\end{array}$ \\
\hline Choicesana & California, USA & Small to medium & $+/-$ & Midseason ripening, vigorous tree, good flavor \\
\hline Coolidge & California, USA/Australia? & Medium & + & $\begin{array}{l}\text { Developed in 1913; Coolidge Rare Plant Garden, } \\
\text { Pasadena, CA }\end{array}$ \\
\hline Edenvale & Santa Cruz, CA, USA & Large & + & Excellent flavor, precocious and self-fertile. \\
\hline Mammoth & New Zealand & Large & + & Good flavor \\
\hline Nezametz & San Diego, CA, USA & Large & + & Pear-shaped, good flavor, does not darken when cut \\
\hline Precocious & Oregon, USA & Medium & $+/-$ & Early, profuse flowering through a longer season \\
\hline Rannaya (Nakita) & Ukraine & Large & $+/-$ & Compact plant growth habit. \\
\hline Robert & New Zealand & Medium & + & Early ripening, juicy, mild flavor. Highly drought tolerant. \\
\hline Superba & Australia & Medium, & $+/-$ & Straggly tree habit, good flavor \\
\hline Trask & & Medium to large & + & Bud sport of Coolidge, very good flavor, ripens early. \\
\hline Triumph & New Zealand & Medium to large & + & $\begin{array}{l}\text { Short, oval fruits with excellent flavor, midseason } \\
\text { ripening }\end{array}$ \\
\hline Unique & & & + & $\begin{array}{l}\text { The only reliably self-fertile feijoa variety. Ripens early, } \\
\text { unremarkable flavor }\end{array}$ \\
\hline
\end{tabular}

